\title{
Note
}

\section{Prune Extract (Prunus Domestica L.) Suppresses the Proliferation and Induces the Apoptosis of Human Colon Carcinoma Caco-2}

\author{
Takashi FujII ${ }^{1}$, Takao IKAMI ${ }^{1}$, Jin-Wen $\mathrm{XU}^{2}$ and Katsumi IKEDA ${ }^{2}$ \\ ${ }^{1}$ Research and Development Institute, MIKI Corporation, 12-4, Naruohama 3, \\ Nishinomiya, Hyogo 663-8142, Japan \\ ${ }^{2}$ Frontier Health Science, School of Human Environment Science, Mukogawa Women's University, 11-68, \\ Koshien-9banchou, Nishinomiya, Hyogo 663-8179, Japan
}

(Received May 19, 2006)

\begin{abstract}
Summary Prunes are the dried fruits of certain cultivars of Prunus domestica L., and are recognized as a health food. The separated ethanol fraction from concentrated prune juice by DIAION HP-20 (PE) was investigated for cytotoxic effects on two different cancer cell lines in vitro. PE dose-dependently reduced the viable cell number of Caco-2, KATO III, but does not reduce the viable cell number of human normal colon fibroblast cells (CCD-18Co) used as a normal cell model. PE treatment for $24 \mathrm{~h}$ led to apoptotic changes in Caco-2 such as cell shrinkage and blebbed surfaces due to the convolutions of nuclear and plasma membranes and chromatin condensation, but this was not observed in CCD-18Co. PE induced nucleosomal DNA fragmentation typical of apoptosis in Caco-2 after $24 \mathrm{~h}$ of treatment. These results show that PE induced apoptosis in Caco-2. Furthermore, by Caco-2 treatment with $\mathrm{H}_{2} \mathrm{O}_{2}$ chelator catalase and $\mathrm{Ca}^{2+}$-chelator BAPTA/AM, the PE-induced cytotoxic pathway was completely blocked, and the viable cell number of Caco-2 was not affected.
\end{abstract}

Key Words prunes (Prunus domestica L.), apoptosis, Caco-2, KATO III, CCD-18Co

Prunes are the dried fruit of certain cultivars of Prunus domestica L., which belongs to the Rosaceae family that originated in the Caucasus region of western Asia. Prunes have been used medicinally in India in combination with other drugs for the treatment of leukorrhea, irregular menstruation, and debility following miscarriage (1). In recent years, prunes are eaten in the dry state, as juice, and as concentrated prune juice. They are recognized as a health food (2).

In previous studies concerning prunes, it was reported that low-density lipoprotein (LDL) cholesterol in human plasma (3), as well as plasma and liver lipids in rats (4), were lowered by a high intake of the dietary fiber in plums. In addition, prune consumption has been seen to induce bone formation in postmenopausal women (5), and improve bone mineral density loss $(6,7)$ and ovariectomy-induced hypercholesterolemia $(8)$ in rats. Thus, these reports indicate that prunes can improve various diseases, but there are few reports concerning cancer. Many reports have shown that polyphenols can control cancer $(9,10)$. Since several polyphenols such as chlorogenic acid are contained in prunes, they are expected to have an effect on controlling cancer.

The separated ethanol fraction from concentrated prune juice by DIAION HP-20 (PE) was investigated for cytotoxic effects on two different cancer cell lines in vitro. $\mathrm{PE}$ was found to be effective in inhibiting Caco-2 human colon carcinoma and KATO III human stomach carcinoma in vitro. PE reduced the viable cell number

E-mail: fujii@@mikiprune.co.jp and induced apoptosis in Caco-2. These results suggest that the growth inhibitory and apoptosis-inducing effects of PE in cancer cells are crucial pathways for cancer prevention.

\section{Materials and Methods}

Fractionation of concentrated prune juice. Concentrated prune juice, MIKI Prune EXTRACT, was supplied by MIKI Foods Co., Ltd. MIKI Prune EXTRACT was applied to a DIAION HP-20 and partitioned between ethanol and water. The ethanol soluble part was evaporated under reduced pressure. About $25 \mathrm{~g}$ of PE was obtained from $800 \mathrm{~g}$ of MIKI Prune EXTRACT.

Cells and cell culture. Caco-2 human colon carcinoma and CCD-18Co normal human colon fibroblast were maintained in Eagle's MEM supplemented with $10 \%$ heat-inactivated fetal calf serum (FCS) and 1\% nonessential amino acid solution. KATO III human stomach carcinoma was maintained in a combination medium of Eagle's MEM+RPMI1640 supplemented with $10 \%$ heat-inactivated FCS. All cell lines were cultured at $37^{\circ} \mathrm{C}$ in a humidified $5 \% \mathrm{CO}_{2}$ atmosphere.

Cell viability assay. The effects of $\mathrm{PE}$ on cellular viability were determined by a 2-(2-methoxy-4-nitrophenyl)-3-(4-nitrophenyl)-5-(2,4-disulfophenyl)-2H-tetrazolium (WST-8) assay using a commercial kit (Tetra Color ONE, Seikagaku Corporation). Briefly, $1 \times 10^{4}$ cells in $1 \mathrm{~mL}$ medium were plated on a 24-well microplate and incubated for $48 \mathrm{~h}$ for attachment. The medium was then replaced with the same amount of new medium with several concentrations of PE added. After incuba- 
tion, it was replaced with new medium supplemented with $10 \%$ WST-8. After $1 \mathrm{~h}$ of incubation, the formation on formazan was determined photometrically at $450 \mathrm{~nm}$ with a microplate reader. The results are shown as the ratio of figures tested to the untreated control, and all analyses were performed on sets of four wells.

A
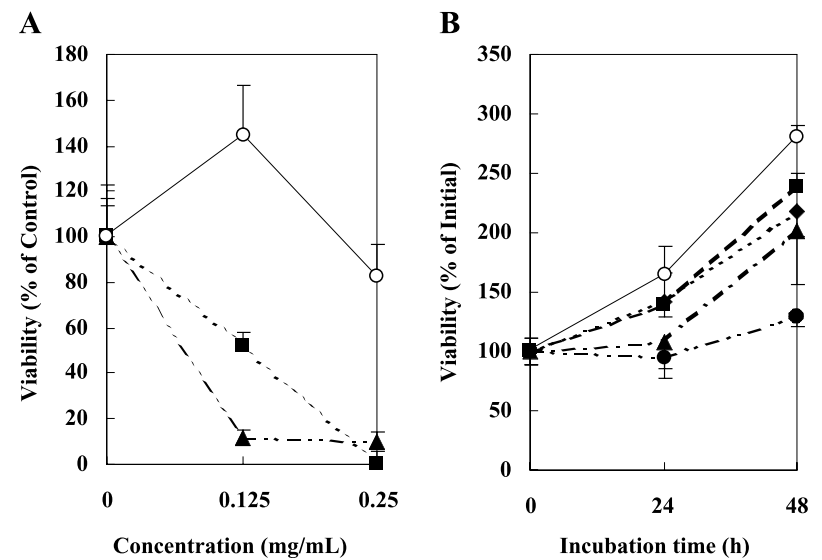

Fig. 1. Effect of PE on the growth of cancer cells. (A) Effect of PE on cell viability of Caco-2, KATO III, and CCD-18Co. Cells were incubated with PE for $24 \mathrm{~h}$ in a medium supplemented with $0.3 \%$ FCS. Results are presented relative to cell growth under control conditions (absence of PE). Each value is the mean \pm SD for sets of four wells. $\mathbf{\square}$, Caco-2; $\mathbf{\Delta}$, KATO III; O, CCD-18Co. (B) Effect of PE on the growth of Caco-2. Caco-2 was incubated with PE for 24 and $48 \mathrm{~h}$ in a medium supplemented with $10 \%$ FCS. Each value is the mean \pm SD for sets of four wells. $\bigcirc$, None; $\mathbf{\square}, 0.13 \mathrm{mg} / \mathrm{mL} ; \boldsymbol{\Lambda}$ $0.25 \mathrm{mg} / \mathrm{mL} ; \diamond, 0.50 \mathrm{mg} / \mathrm{mL} ; \bullet, 1.0 \mathrm{mg} / \mathrm{mL}$.
DNA extraction and agarose gel electrophoresis. DNA fragmentation was determined using a commercial kit (Quick Apoptotic DNA Ladder Detection Kit, BioVision). Briefly, cells (approximately $5 \times 10^{5}$ cells) were lysed in $40 \mu \mathrm{L}$ of Tris-EDTA lysis buffer, incubated with a $5 \mu \mathrm{L}$ Enzyme A (RNase) solution at $37^{\circ} \mathrm{C}$ for $10 \mathrm{~min}$, and then incubated with a $5 \mu \mathrm{L}$ Enzyme B (Proteinase K) solution at $50^{\circ} \mathrm{C}$ for $30 \mathrm{~min}$. DNA was then precipitated with isopropanol and resuspended in DNA suspension buffer. DNA were electrophoresed in Tris-borate buffer on $1 \%$ agarose gel and stained with ethidium bromide.

Cell morphology. To assess morphological changes, cells were treated with the PE concentrations mentioned above. After treatment, photographs were taken using a phase-contrast microscope.

\section{Results and Discussion}

Initially, the effects of PE on cell viability were examined. PE was added to a medium supplemented with $0.3 \%$ FCS of Caco-2, KATO III and CCD-18Co, and incubated for $24 \mathrm{~h}$. PE dose-dependently reduced the viable cell number of Caco-2 and KATO III, but did not reduce the viable cell number of CCD-18Co (Fig. 1A). In the medium supplemented with 10\% FCS, PE dose-dependently inhibited the proliferation of Caco-2 following 24 and $48 \mathrm{~h}$ of incubation (Fig. 1B).

Figure 2 shows the apoptosis-inducing effects of $\mathrm{PE}$ on Caco-2. Treatment of Caco-2 with PE had a remarkable effect on the cell morphology. The $0.25 \mathrm{mg} / \mathrm{mL}$ PE treatment for $24 \mathrm{~h}$ led to apoptotic changes such as cell shrinkage and blebbed surfaces due to the convolutions

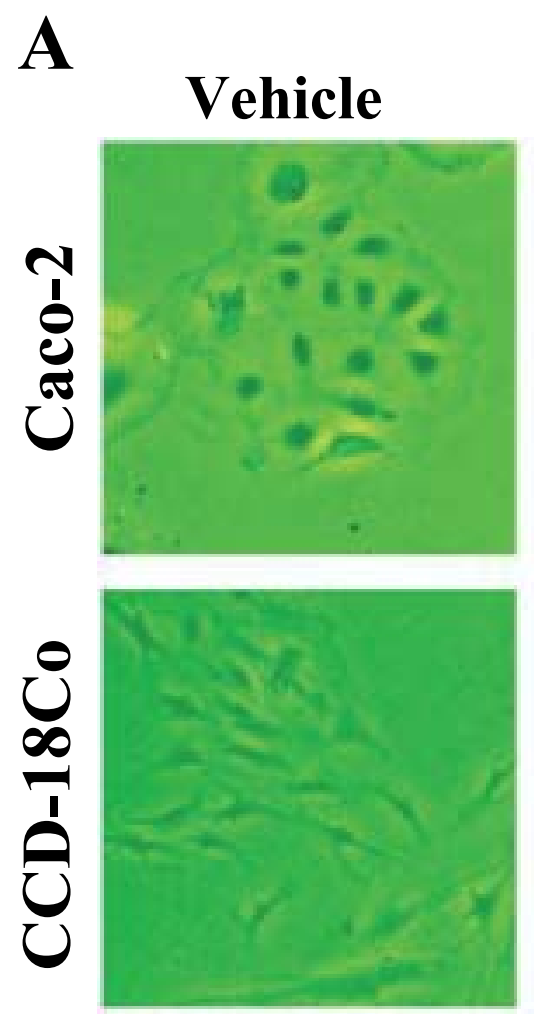

\section{PE $(0.25 \mathrm{mg} / \mathrm{mL})$}
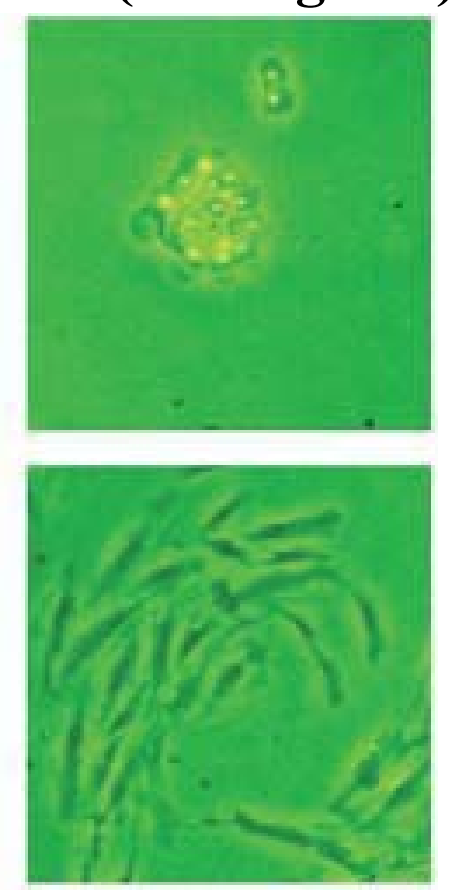

B

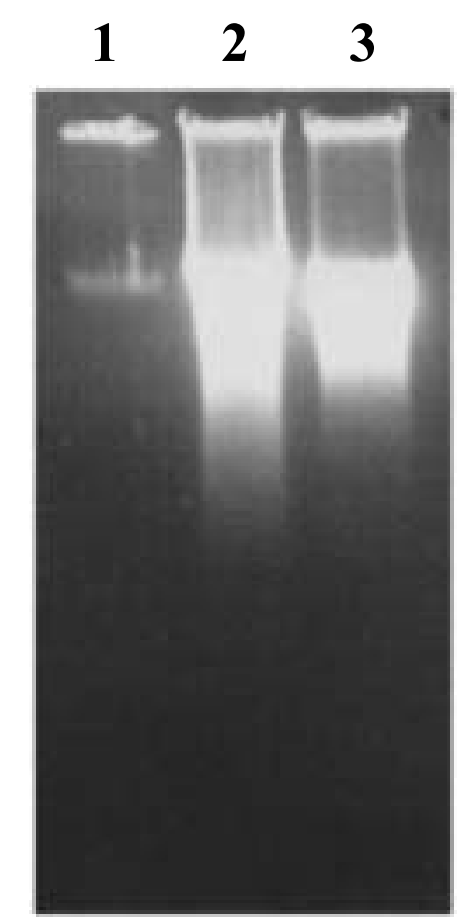

Fig. 2. Apoptosis-inducing effects of PE on Caco-2. (A) Morphological changes of Caco-2 and CCD-18Co after $24 \mathrm{~h}$ of treatment with PE in a medium supplemented with $0.3 \%$ FCS $(200 \times$ magnification). (B) Analysis of DNA fragmentation patterns by agarose gel electrophoresis. DNA was extracted from Caco-2 treated with vehicle (lane 1), $0.25 \mathrm{mg} / \mathrm{mL} \mathrm{PE}$ (lane 2), and $500 \mu \mathrm{M} \mathrm{H}_{2} \mathrm{O}_{2}$ (lane 3, as a positive control) for $24 \mathrm{~h}$ in a medium supplemented with $0.3 \% \mathrm{FCS}$. 


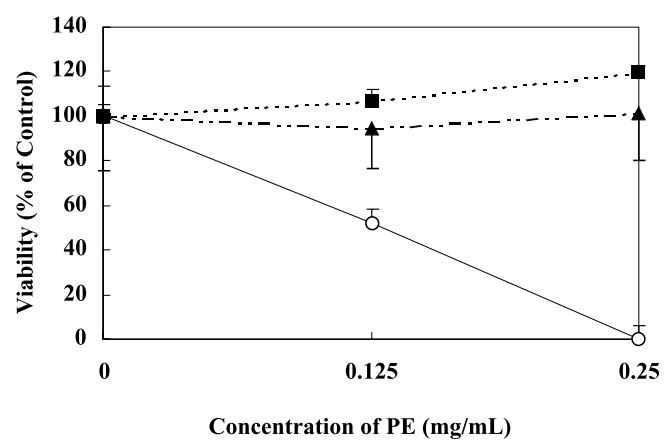

Fig. 3. Effects of inhibitors on PE-induced cell death in Caco-2. Caco-2 was incubated with PE and the inhibitor for $24 \mathrm{~h}$ in a medium supplemented with $0.3 \%$ FCS. Each value is the mean \pm SD for sets of four wells. $\bigcirc$, None; $\mathbf{\square}$, BAPTA/AM; $\mathbf{\Delta}$, catalase.

of nuclear and plasma membranes and chromatin condensation, but this was not observed in CCD-18Co (Fig. 2A). PE induced nucleosomal DNA fragmentation typical of apoptosis in Caco-2 after $24 \mathrm{~h}$ of treatment (Fig. 2B). These results show that PE induced apoptosis in Caco-2. The main chemical compound contained in prunes is chlorogenic acid, which accounts for about $10 \%$ of PE (11). There is a report that chlorogenic acid produces large DNA fragments and nuclear condensation, and activates caspase in human oral tumor cells (12). However, a number of reports have demonstrated that chlorogenic acid has little modulating effect on cell viability and the apoptosis of cancer cells in vitro (10, 13). In fact, we have data that $1 \mathrm{~mm}$ chlorogenic acid has no effect on the viability of Caco-2 (data not shown). These data might indicate an important role together with other chemical compounds in controlling cancer cell proliferation in vivo also, possibly by synergistic effects.

Figure 3 shows the effects of inhibitors on PEinduced cell death in Caco-2. PE dose-dependently reduced the viable cell number of Caco-2. When Caco-2 was treated with $\mathrm{H}_{2} \mathrm{O}_{2}$ chelator catalase $(3,000 \mathrm{U} / \mathrm{mL})$, the PE-induced cytotoxic pathway was completely blocked, and the viable cell number of Caco-2 was not affected (Fig. 3). BAPTA/AM $(250 \mu \mathrm{M})$, which penetrates the cell subsequent to hydrolysis to BAPTA, which serves as an intracellular $\mathrm{Ca}^{2+}$ chelator, also completely abolished the reduction in the viable cell number of Caco-2 (Fig. 3). Disruption of cellular reactive oxygen species (ROS) and $\mathrm{Ca}^{2+}$ homeostasis has been proposed as a critical event in both apoptosis and necrosis (14). The involvement of increased $\mathrm{Ca}^{2+}$ was reported in cells undergoing apoptosis in many different settings. Similarly, ROS is related to apoptosis. Recently, many $\mathrm{H}_{2} \mathrm{O}_{2}$-sensitive transcription factors (such as AP1 , NF- $\kappa \mathrm{B})$, which are related to apoptosis, have been reported $(15,16)$. Further study is required to test factors inducing apoptosis.

In summary, the effects of PE on cell viability and apoptosis were evaluated. PE had apoptosis-inducing effects, some of which involved cellular $\mathrm{H}_{2} \mathrm{O}_{2}$ and $\mathrm{Ca}^{2+}$. These results suggest that PE might exert cancer-preventive action through apoptosis- and/or cell prolifera- tion-dependent mechanisms.

\section{REFERENCES}

1) Chopra RN, Nayar SC, Chopra IC. 1956. Glossary of Indian Medical Plants, p 205. CSIR, New Delhi, India.

2) Stacewicz-Sapuntzakis M, Bowen PE, Hussain EA, Damayanti-Wood BI, Farnsworth NR. 2001. Chemical composition and potential health effects of prunes: a functional food? Crit Rev Food Sci Nutr 41: 251-286.

3) Tinker LF, Schneeman BO, Davis PA, Gallaher DD, Waggoner CR. 1991. Consumption of prunes as a source of dietary fiber in men with mild hypercholesterolemia. Am J Clin Nutr 53: 1259-1265.

4) Tinker LF, Davis PA, Schneeman BO. 1994. Prune fiber or pectin compared with cellulose lowers plasma and liver lipids in rats with diet-induced hyperlipidemia. J Nutr 124: 31-40.

5) Arjmandi BH, Khalil DA, Lucas EA, Georgis A, Stoecher BJ, Hardin C, Payton ME, Wild RA. 2002. Dried plums improve indices of bone formation in postmenopausal women. J Womens Health Gend Based Med 11: 61-68.

6) Arjmandi BH, Wang C, Zhang Y, Lucas E, Soliman A, Juma S, Stoecker BJ. 1999. Prune: its efficacy in prevention of ovarian hormone deficiency-induced bone loss. J Bone Miner Res 14: S515.

7) Deyhim F, Lucas E, Brucsewitz G, Stoecker BJ, Arjmandi H. 1999. Prune dose-dependently reverses bone loss in ovarian hormone-deficient rats. J Bone Miner Res 14: S394.

8) Edralin AL, Shanil J, Barbara JS, Bahram HA. 2000. Prune suppresses ovariectomy-induced hypercholesterolemia in rats. J Nutr Biochem 11: 255-259.

9) Ito H, Gonthier MP, Manach C, Morand C, Mennen L, Remesy C, Scalbert A. 2005. Polyphenol levels in human urine after the intake of six different polyphenol-rich beverages. Br J Nutr 94: 500-509.

10) Ramos S, Alia M, Bravo L, Goya L. 2005. Comparative effects of food-derived polyphenols on the viability and apoptosis of a human hepatoma cell line (HepG2). J Agric Food Chem 53: 1271-1280.

11) Kayano S, Yamada NF, Suzuki T, Ikami T, Shioaki K, Kikuzaki H, Mitani T, Nakatani N. 2003. Quantitative evaluation of antioxidant components in prunes (Prunus domestica L.). J Agric Food Chem 51: 1480-1485.

12) Jiang Y, Kusama K, Satoh K, Takayama E, Watanabe S, Sakagami H. 2000. Induction of cytotoxicity by chlorogenic acid in human oral tumor cell lines. Phytomedicine 7: 483-491.

13) Zheng Q, Hirose Y, Yoshimi N, Murakami A, Koshimizu K, Ohigashi H, Sakata K, Matsumoto Y, Sayama Y, Mori H. 2002. Further investigation of the modifying effect of various chemopreventive agents on apoptosis and cell proliferation in human colon cancer cells. J Cancer Res Clin Oncol 128: 539-546.

14) Park EK, Kwon KB, Park KI, Park BH, Jhee EC. 2002. Role of $\mathrm{Ca}^{2+}$ in diallyl disulfide-induced apoptotic cell death of HCT-15 cells. Exp Mol Med 34: 250-257.

15) Mates JM, Sanchez-Jimenez FM. 2000. Role of reactive oxygen species in apoptosis: implications for cancer therapy. Int J Biochem Cell Biol 32: 157-170.

16) Vollgraf U, Wegner M, Richter-Landsberg C. 1999. Activation of AP-1 and nuclear factor-kappaB transcription factors is involved in hydrogen peroxide-induced apoptotic cell death of oligodendrocytes. J Neurochem 73: 2501-2509. 